\title{
Analisis Kepuasan Pelanggan Pada Sekolah Tinggi Teknologi Muhammadiyah Cileungsi-Bogor
}

\author{
Awang Surya* \\ Program Studi Teknik Mesin, Sekolah Tinggi Teknologi Muhammadiyah Cileungsi \\ Jl. Anggrek No.25, Perum. PTSC, Kec. Cileungsi, Kab. Bogor, Jawa Barat 16820 \\ *Email: awang_surya@yahoo.com
}

\begin{abstract}
Background The competition between each university to reach prospective students is getting tighter and tighter. Therefore, the efforts of the university to satisfy customers, in this case, students, are becoming increasingly important. Satisfied customers are the most effective promotional media, because they will promote to other potential customers. Vice versa, disappointed customers will become a bad promotion media. All efforts to recruit potential customers will be ineffective when consumers are disappointed to do negative campaigns.

Aim So it becomes important to know the level of customer satisfaction, namely students of the Muhammadiyah University of Cileungsi, so that STTM Cileungsi can win the competition to win the hearts of prospective students.

Method This research was conducted by interviewing several customer samples, namely 82 students from STT Muhammadiyah Cileungsi, from three study programs at STT Muhammadiyah Cileungsi. The analysis method used is to use Importance Performance Analysis.

Result Sequentially according to the suitability level of these factors are: Internet facilities (55.76\%), Quality of lecture rooms (60.27\%), Accreditation status (60.73\%), Building ownership status (62.50\%), Exchange employment (63.38\%), Completeness of laboratories (66.67\%) and Completeness of reference books in the campus library (69.86\%).

Conclusion From the research results obtained several factors that need serious attention because customer expectations are high but the performance of these factors is low. The output of this research is a paper that will be published in the internal journal of the Muhammadiyah University of Cileungsi, Teknosains.
\end{abstract}

Keywords: Customer satisfaction, STT Muhammadiyah Cileungsi, Importance Performance Analysis

\section{PENDAHULUAN}

Kesadaran akan pendidikan semakin tumbuh di wilayah Kabupaten Bogor dan sekitarnya. Antusiasme melanjutkan ke jenjang pendidikan tinggi juga terasa meningkat. Tentu saja hal ini cukup menggembirakan bagi para pengelola pendidikan tinggi, karena pasar semakin membesar. Tetapi tentu saja mengembangnya pasar tidak serta merta akan berdampak bertambahnya jumlah mahasiswa yang mendaftar kepada setiap perguruan tinggi.

Dengan letak geografis Kecamatan Cileungsi yang cukup dekat dengan ibu kota negara Jakarta dan Kota Bekasi, serta adanya sarana transportasi yang cukup memadai, maka setiap perguruan tinggi mempunyai daya tawar yang hampir sama bagi calon mahasiswa. Apalagi hampir setiap keluarga di

Teknosains : Jurnal Sains, Teknologi dan Informatika is licensed under a Creative Commons Attribution-NonCommercial 4.0 International License. 
wilayah Jabodetabek dan sekitarnya memiliki sarana transportasi berupa sepeda motor, yang pasti memudahkan jika ada anggota keluarga yang hendak menempuh pendidikan di kota-kota sekitar Kabupaten Bogor terutama di wilayah Jabodetabek.

Maka masing-masing perguruan tinggi dituntut untuk melakukan tindakan-tindakan tertentu agar tetap eksis. Jika tidak, maka lambat laun perguruan tinggi tersebut akan ditinggalkan mahasiswa dan akhirnya mati. Dalam persaingan yang semakin sengit ini tentu saja kepuasan pelanggan (Durvasula, Lysonski, \& Mehta, 1999) menjadi sangat penting. Perguruan tinggi yang mampu memuaskan mahasiswanya akan menjadi pilihan calon mahasiswa dan yang mengecewakan akan ditinggalkan.

Berdasarkan uraian di atas menjadi penting untuk diketahui seberapa besar tingat kepuasan mahasiswa Sekolah Tinggi Teknologi Muhammadiyah Cileungsi. Faktor-faktor apa saja yang dianggap memuaskan dan faktor-faktor apa saja yang masih mengecewakan (Cox, 1986).

Pelanggan adalah seorang individu yang secara kontinyu dan berulang kali datang ke tempat yang sama untuk memuaskan keinginannya dengan memiliki suatu produk atau mendapatkan suatu jasa dan memuaskan produk atau jasa tersebut (Lupiyoadi, 2014).

Secara umum pelanggan dikelompokkan menjadi dua yaitu pelanggan internal dan pelanggan eksternal. Pelanggan internal adalah pelanggan yang ada di dalam perusahaan itu sendiri. Mereka itu adalah pihak-pihak yang menjadi pengguna hasil kerja dari pihak yang bekerja pada bagian sebelumnya. Di sebuah pabrik roti, sebagai contoh, ada beberapa proses yang harus dilakukan sebelum menghasilkan produk sebuah roti yang dibeli konsumen. Beberapa di antaranya adalah penimbangan bahan, pencampuran adonan, pembentukan dan pemasakan. Dalam hal ini bagian pencampur adonan adalah pelanggan dari bagian penimbangan bahan. Jika penimbangan tidak sesuai ukuran yang sudah ditentukan maka proses pengadonan tidak akan menghasilkan adonan yang maksimal, dan karena itu bagian pencampur adonan bisa kecewa. Pelanggan eksternal adalah pelanggan yang datang dari luar perusahaan, yang membeli barang atau jasa yang dihasilkan oleh perusahaan.

Kepuasan pelanggan adalah tingkat perasaan seseorang setelah membandingkan kinerja (atau hasil) yang ia rasakan dibandingkan dengan harapannya (Kotler, 2011). Jadi tingkat kepuasan merupakan fungsi dari perbedaan antara kinerja yang dirasakan dengan harapan. Apabila kinerja di bawah harapan, pelanggan kecewa. Bila kinerja sesuai dengan harapan, pelanggan akan puas. Sedangkan bila kinerja melebihi harapan, pelanggan akan sangat puas. Harapan pelanggan dapat dibentuk oleh pengalaman masa lampau, komentar dari kerabat serta janji dan informasi pemasar dan saingannya. Pelanggan yang puas akan setia lebih lama, kurang sensitif terhadap harga dan memberi komentar yang baik tentang perusahaan (Supranto, 2001).

Sudah menjadi pendapat umum bahwa jika konsumen merasa puas dengan suatu produk atau merek, mereka cenderung akan terus membeli dan menggunakannya serta memberitahu orang lain tentang pengalaman mereka yang menyenangkan dengan produk tersebut. Jika merasa tidak dipuaskan, mereka cenderung beralih merek serta mengajukkan keberatan pada produsen, pengecer, dan bahkan menceritakannya kepada konsumen lainnya. Kepuasan konsumen merupakan suatu hal yang sangat berharga demi mempertahankan keberadaan konsumen tersebut untuk tetap berjalannya suatu bisnis atau usaha. Layanan yang diberikan kepada konsumen akan memacu puas tidaknya seorang konsumen

\section{Teknosains : Jurnal Sains,Teknologi dan Informatika is licensed under a Creative Commons} Attribution-NonCommercial 4.0 International License. 
atas pelayanan yang diberikan ("FAKTOR-FAKTOR KEPUASAN PELANGGAN DAN LOYALITAS PELANGGAN: Studi Kasus Pada CV. Sarana Media Advertising Surabaya,” 2004).

Kepuasan pelanggan dapat diukur dengan berbagai metode dan teknik. Menurut Philip Kotler beberapa macam metode pengukuran kepuasan pelanggan adalah sebagai berikut:

1. Sistem keluhan dan saran

Pada metode ini pelanggan diberikan ruang untuk menyampaikan saran, pendapat dan keluhan terhadap produk atau jasa yang kita tawarkan. Perlu juga dipertimbangkan presiasi agar pelanggan tertarik untuk memberikan masukan. Ada banyak media yang dapat digunakan untuk menampung pesan dari mereka. Salah satu contohnya adalah kotak saran, p.o box. Sedangkan pada era digital seperti saat ini bisa menggunakan email atau nomor WA.

2. Ghost shooping

Cara ini dilakukan dengan mempekerjakan beberapa orang untuk berperan sebagai pembeli. Bisa jadi mereka membeli produk perusahaan sendiri atau perusahaan pesaing. Selanjutnya pembeli bayangan ini melaporkan hasil dari pengalaman mereka membeli produk perusahaan atau pesaing.

3. Analisa pelanggan yang hilang (Lost customer analisys).

Pada cara ini, perusahaan-perusahaan mencoba untuk menghubungi para pelanggan yang telah berhenti membeli produk perusahaan ataupun telah berpindah pada pemasok lain. Hal ini dilakukan untuk untuk alasan pelanggan berhenti menggunakan produk perusahaan atau berpindah ke produk lain.

4. Survei kepuasan pelanggan

Perusahaan harus menghubungi para pelanggan dan bertanya langsung untuk mengetahui tingkat kepuasan pelanggan (Kotler, 2011).

Importance-Performance Analysis (IPA) adalah sebuah teknik analisis deskriptif yang diperkenalkan oleh John A. Martilla dan John C. James pada tahun 1977. Importance-Performance Analysis adalah suatu teknik analisis yang digunakan untuk mengidentifikasi faktor-faktor kinerja penting apa saja yang harus ditunjukkan oleh suatu organisasi dalam memenuhi kepuasan para pengguna jasa (konsumen)(Suhendra \& Prasetyanto, 2016). Adapun langkah-langkah analisis IPA adalah sebagai berikut:

1. Mencari Harga Tingkat Kesesuaian.

Tingkat kesesuaian adalah hasil perbandingan skor kinerja dengan skor kepentingan. Untuk mengetahui apakah kinerja produk sudah sesuai dengan kepentingan para pembeli atau pengguna. Adapun rumus yang digunakan adalah:

$$
\mathrm{Tki}=\frac{\mathrm{Xi}}{\mathrm{Yi}} \times 100 \%
$$

(John Martila and John C. James yang dikutip oleh J. Supranto, 2011: 241).

Keterangan:

Tki $=$ Tingkat kesesuaian responden .

$\mathrm{Xi}=$ Skor penilaian kinerja perusahaan/produk

$\mathrm{Yi}=$ Skor penilaian kepentingan pelanggan

Teknosains : Jurnal Sains, Teknologi dan Informatika is licensed under a Creative Commons Attribution-NonCommercial 4.0 International License. 
Sumbu mendatar (X) akan diisi oleh skor tingkat kinerja, sedangkan sumbu tegak (Y) akan diisi oleh skor tingkat kepentingan. Dalam penyederhanaan rumus, maka untuk setiap atribut yang mempengaruhi kepuasan konsumen dapat diketahui dengan rumus:

$\overline{\mathrm{X}}=\frac{\sum \mathrm{Xi}}{\mathrm{n}} \quad \overline{\mathrm{Y}}=\frac{\sum \mathrm{Yi}}{\mathrm{n}}$

(J. Supranto, 2011: 241).

2. Membuat Diagram Kartesius.

Diagram kartesius digunakan untuk mengetahui indikator jasa pelayanan yang memuaskan atau tidak memuaskan konsumen. Rumus yang digunakan adalah:

$$
\overline{\bar{X}}=\frac{\sum_{i=1}^{N} \overline{\bar{X}}}{K} \quad \quad \overline{\bar{Y}}=\frac{\sum_{i=1}^{N} \overline{\bar{Y}}}{K}
$$

(J. Supranto, 2011: 242).

dimana, $\mathrm{K}=$ Banyaknya atribut atau fakta yang dapat mempengaruhi kepuasan pelanggan.

Diagram kartesius digunakan untuk memetakan atibut-atribut kualitas produk yang telah dianalisis, dengan gambar sebagai berikut:

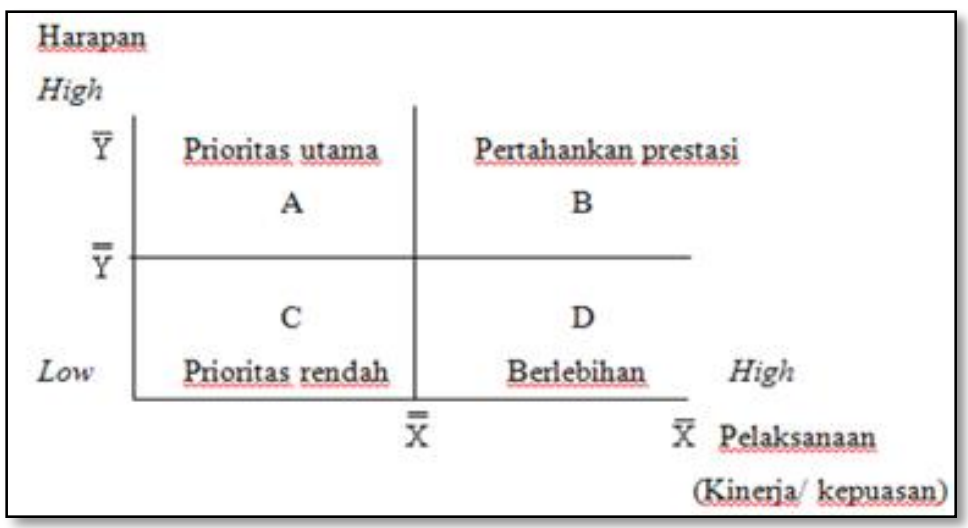

Gambar 1. Diagram Kartesius

Keterangan:

A. Menunjukkan faktor atau atribut yang dianggap mempengaruhi kepuasan pelanggan, yang dianggap sangat penting, namun belum sesuai dengan keinginan pelanggan. Inilah wilayah yang harus mendapat perhatian serius.

B. Menunjukkan unsur jasa pokok yang telah berhasil dilaksanakan. Untuk itu wajib dipertahankan, dianggap sangat penting dan sangat memuaskan.

C. Menunjukkan beberapa faktor yang kurang penting pengaruhnya bagi pelanggan. Pelaksanaannya oleh perusahaan biasa-biasa saja. Dianggap kurang penting dan kurang memuaskan.

Teknosains : Jurnal Sains, Teknologi dan Informatika is licensed under a Creative Commons Attribution-NonCommercial 4.0 International License.

Analisis Kepuasan Pelanggan Pada Sekolah Tinggi Teknologi Muhammadiyah Cileungsi-Bogor (Vol.7, No.1) Januari 2020 
D. Menunjukkan faktor yang mempengaruhi pelanggan kurang penting, akan tetapi pelaksanaannya berlebihan, dianggap kurang penting tetapi sangat memuaskan.

\section{Penentuan jumlah sampel}

Banyak rumus pengambilan sampel penelitian yang dapat digunakan untuk menentukan jumlah sampel penelitian. Pada prinsipnya penggunaan rumus-rumus penarikan sample penelitian digunakan untuk mempermudah teknis penelitian. Sebagai misal, bila populasi penelitian terbilang sangat banyak atau mencapai jumlah ribuan atau wilayah populasi terlalu luas, maka penggunaan rumus pengambilan sample tertentu dimaksudkan untuk memperkecil jumlah pengambilan sampel atau mempersempit wilayah populasi agar teknis penelitian menjadi lancar dan efisien. Salah satu teknik praktis pengambilan sampel yang paling banyak digunakan dalam penelitian adalah Rumus Slovin yaitu sebagai berikut :

Rumus Slovin adalah sebuah rumus atau formula untuk menghitung jumlah sampel minimal apabila perilaku dari sebuah populasi tidak diketahui secara pasti. Rumus ini pertama kali diperkenalkan oleh Slovin pada tahun 1960. Rumus Slovin ini biasa digunakan dalam penelitian survey dimana biasanya jumlah sampel besar sekali, sehingga diperlukan sebuah formula untuk mendapatkan sampel yang sedikit tetapi dapat mewakili keseluruhan populasi.

Rumus Slovin (Ong \& Pambudi, 2014) dapat dilihat berdasarkan notasi sebagai berikut:

$\mathrm{n}=\frac{\mathrm{N}}{1+\mathrm{N}\left(\mathrm{e}^{2}\right)}$

Dimana:

$\mathrm{n}=$ ukuran sampel

$\mathrm{N}=$ ukuran populasi

$\mathrm{e}=$ persen kelonggaran ketidaktelitian karena kesalahan pengambilan sampel yang masih dapat ditolerir atau diinginkan, misalnya $10 \%$.

\section{METODE}

A. Tujuan Operasional Penelitian

1. Untuk mengetahui tingkat kepuasan mahasiswa STT Muhammadiyah Cileungsi

2. Untuk mendapatkan gambaran atribut-atribut apa yang dianggap penting dan tidak penting serta bagaimana pencapaiannya di mata pelanggan.

B. Tempat dan Waktu Penelitian

Penelitian dilakukan di STT Muhammadiyah Cileungsi, Kecamatan Cileungsi, Kabupaten Bogor, Provinsi Jawa Barat.

D. Populasi

Populasi adalah keseluruhan obyek yang akan diteliti. Dalam penelitian ini anggota populasi yang akan diteliti adalah mahasiswa STT Muhammadiyah Cileungsi, Kecamatan Cileungsi, Kabupaten Bogor, Provinsi Jawa Barat.

Teknosains : Jurnal Sains, Teknologi dan Informatika is licensed under a Creative Commons Attribution-NonCommercial 4.0 International License. 
E. Teknik Pengumpulan Data

1. Tahap persiapan

Penyusunan Instrumen penelitian (angket):

1. Penyusunan rancangan angket

2. Uji coba angket

3. Revisi Angket

4. Penggandaan Angket

2. Tahapan Pelaksanaan

a. Pengumpulan data

b. Dokumentasi

F. Teknik Analisa Data

Analisa data menggunakan IPA (Importance Performance Analysis)

\section{HASIL DAN PEMBAHASAN}

3.1 Variabel Penelitian

Beberapa faktor yang diukur di dalam penelitian ini adalah sebagai berikut:

Tabel 1. Variabel Penelitian

\begin{tabular}{|c|l|}
\hline NO. & \multicolumn{1}{|c|}{ FAKTOR } \\
\hline 1 & Kelengkapan buku-buku referensi di perpustakaan kampus \\
\hline 2 & Kelengkapan laboratorium \\
\hline 3 & $\begin{array}{l}\text { Kualitas dosen (kualifikasi pendidikan dan pengalaman yang berkaitan dengan mata kuliah yang } \\
\text { diampu) }\end{array}$ \\
\hline 4 & Kemampuan dosen mengajar di kelas \\
\hline 5 & Tingkat kehadiran dosen \\
\hline 6 & Kemudahan prosedur pelayanan administrasi (pendaftaran, pembayaran dan lain-lain) \\
\hline 7 & $\begin{array}{l}\text { Kejelasan dan konsistensi peraturan berkaitan dengan akademik (perkuliahan, kerja praktek, } \\
\text { praktikum, tugas akhir dan lain-lain) }\end{array}$ \\
\hline 8 & Pelayanan dan bimbingan dari Dosen mata kuliah, Dosen wali dan Kaprodi \\
\hline 9 & Keramahan petugas pelayanan di kampus (akademik, keuangan, perpustakaan dan lain-lain) \\
\hline 10 & Kelengkapan sarana ibadah \\
\hline 11 & Kelengkapan sarana olahraga \\
\hline 12 & Letak kampus (strategis, mudah dijangkau dan lain-lain) \\
\hline 13 & Biaya-biaya \\
\hline 14 & Status akreditasi \\
\hline 15 & Status kepemilikan gedung \\
\hline 16 & Kualitas ruang kuliah \\
\hline 17 & Fleksibilitas waktu kuliah \\
\hline 18 & Keterkaitan mata kuliah dengan perkembangan perkembangan zaman \\
\hline 19 & Ketersediaan modul/buku untuk masing-masing mata kuliah \\
\hline 20 & Ketersediaan tempat makan minum (kantin, kafe dan lain-lain) \\
\hline 21 & Keaktifan ikatan alumni \\
\hline 22 & Bursa lapangan kerja \\
\hline 23 & Keaktifan lembaga kemahasiswaan \\
\hline
\end{tabular}

\section{Teknosains : Jurnal Sains, Teknologi dan Informatika is licensed under a Creative Commons} Attribution-NonCommercial 4.0 International License.

Analisis Kepuasan Pelanggan Pada Sekolah Tinggi Teknologi Muhammadiyah Cileungsi-Bogor (Vol.7, No.1) Januari 2020 


\begin{tabular}{|l|l|}
\hline 24 & Kualitas tempat parkir kendaraan \\
\hline 25 & Fasilitas internet \\
\hline
\end{tabular}

Skala likert yang digunakan dalam kuesioner berjumlah 5 skala likert. Untuk kuisioner tingkat kepentingan faktor di atas digunakan skala sebagai berikut:

$1=$ SANGAT TIDAK PENTING

$2=$ TIDAK PENTING

$3=$ BIASA

$4=$ PENTING

$5=$ SANGAT PENTING

Sedangkan untuk kuisioner tingkat kinerja dipergunakan skala sebagai berikut:

$1=$ SANGAT TIDAK MEMUASKAN

$2=$ TIDAK MEMUASKAN

$3=$ BIASA

$4=$ MEMUASKAN

$5=$ SANGAT MEMUASKAN

Data utama dari penelitian ini adalah jumlah pelanggan STT Muhammadiyah Cileungsi, yang dalam hal ini adalah pelanggan eksternal yaitu mahasiswa. Untuk data terakhir mahasiswa pada semester genap tahun ajaran 2018/2019 adalah sebagai berikut:

Table 2. Jumlah Mahasiswa STT Muhammadiyah Cileungsi

\begin{tabular}{|r|c|c|}
\hline \multicolumn{1}{|c|}{ PRODI } & JUMLAH MAHASIWA & PORSI \\
\hline Teknik Mesin & 84 & 0.19 \\
\hline Teknik Industri & 197 & 0.44 \\
\hline Teknik Informatika & 165 & 0.37 \\
\hline TOTAL & 446 & \\
\hline
\end{tabular}

Dengan data tersebut di atas, maka dengan menggunakan Rumus Slovin, serta dengan menggunakan tingkat kesalahan $10 \%$ maka diperoleh angka sampel sebagai berikut:

$$
\begin{gathered}
n=\frac{N}{1+N\left(e^{2}\right)} \\
n=\frac{446}{1+446\left(0.1^{2}\right)} \\
n=81.68 \text { atau } 82
\end{gathered}
$$

Maka sampel minimal yang diambil untuk penelitian ini adalah 82. Dengan memperhatikan proporsi jumlah mahasiswa di masing-masing prodi, maka jumlah sampel penelitian untuk masingmasing prodi adalah sebagai berikut:

Teknosains : Jurnal Sains,Teknologi dan Informatika is licensed under a Creative Commons Attribution-NonCommercial 4.0 International License.

Analisis Kepuasan Pelanggan Pada Sekolah Tinggi Teknologi Muhammadiyah Cileungsi-Bogor (Vol.7, No.1) Januari 2020 
TEKNOSAINS: Jurnal Sains, Teknologi dan Informatika, Vol.7, No. 1, Januari 2020, 43 - 56

http://jurnal.sttmcileungsi.ac.id/index.php/tekno

Tabel 3. Jumlah sampel penelitian setiap prodi.

\begin{tabular}{|l|c|c|}
\hline \multicolumn{1}{|c|}{ PRODI } & PROPORSI & SAMPEL \\
\hline Teknik Mesin & 0.19 & 16 \\
\hline Teknik Industri & 0.44 & 36 \\
\hline Teknik Informatika & 0.37 & 30 \\
\hline \multicolumn{1}{|c|}{ TOTAL } & 1 & 82 \\
\hline
\end{tabular}

Dari hasil pelaksanaan survey kepada 82 orang yang menjadi sampel populasi didapat hasil penilaian masing-masing faktor sebagai berikut:

Tabel 4. Nilai kepentingan masing-masing faktor

\begin{tabular}{|c|c|c|c|c|c|c|c|}
\hline & \multicolumn{5}{|c|}{ NILAI } & TOTAL & NIKi \\
\hline VARIABEL & STP & $\mathrm{TP}$ & B & $\mathrm{P}$ & SP & & \\
\hline & 1 & 2 & 3 & 4 & 5 & & \\
\hline 1 & 0 & 1 & 13 & 26 & 42 & 82 & 355 \\
\hline 2 & 0 & 1 & 11 & 19 & 51 & 82 & 366 \\
\hline 3 & 0 & 0 & 3 & 28 & 51 & 82 & 376 \\
\hline 4 & 0 & 0 & 4 & 29 & 49 & 82 & 373 \\
\hline 5 & 0 & 0 & 10 & 38 & 34 & 82 & 352 \\
\hline 6 & 0 & 0 & 12 & 37 & 33 & 82 & 349 \\
\hline 7 & 0 & 2 & 14 & 32 & 34 & 82 & 344 \\
\hline 8 & 0 & 0 & 13 & 28 & 41 & 82 & 356 \\
\hline 9 & 0 & 1 & 19 & 25 & 37 & 82 & 344 \\
\hline 10 & 0 & 0 & 4 & 27 & 51 & 82 & 375 \\
\hline 11 & 3 & 5 & 28 & 27 & 19 & 82 & 300 \\
\hline 12 & 0 & 1 & 21 & 33 & 27 & 82 & 332 \\
\hline 13 & 2 & 3 & 21 & 32 & 24 & 82 & 319 \\
\hline 14 & 0 & 1 & 5 & 15 & 61 & 82 & 382 \\
\hline 15 & 1 & 2 & 11 & 18 & 50 & 82 & 360 \\
\hline 16 & 0 & 0 & 10 & 20 & 52 & 82 & 370 \\
\hline 17 & 0 & 0 & 8 & 28 & 46 & 82 & 366 \\
\hline 18 & 0 & 0 & 8 & 32 & 42 & 82 & 362 \\
\hline 19 & 0 & 3 & 12 & 26 & 41 & 82 & 351 \\
\hline 20 & 0 & 2 & 17 & 27 & 36 & 82 & 343 \\
\hline 21 & 4 & 4 & 26 & 31 & 17 & 82 & 299 \\
\hline 22 & 2 & 2 & 13 & 15 & 50 & 82 & 355 \\
\hline 23 & 0 & 3 & 14 & 33 & 32 & 82 & 340 \\
\hline 24 & 0 & 0 & 23 & 23 & 36 & 82 & 341 \\
\hline 25 & 0 & 1 & 8 & 18 & 55 & 82 & 373 \\
\hline
\end{tabular}

Teknosains : Jurnal Sains,Teknologi dan Informatika is licensed under a Creative Commons Attribution-NonCommercial 4.0 International License.

Analisis Kepuasan Pelanggan Pada Sekolah Tinggi Teknologi Muhammadiyah Cileungsi-Bogor (Vol.7, No.1) Januari 2020 
TEKNOSAINS: Jurnal Sains, Teknologi dan Informatika, Vol.7, No. 1, Januari 2020, 43 - 56 http://jurnal.sttmcileungsi.ac.id/index.php/tekno

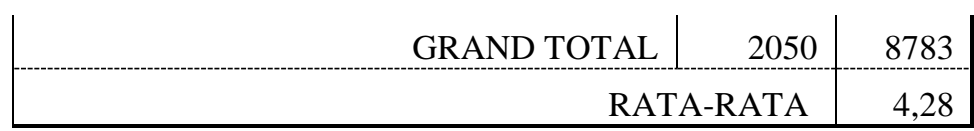

Tabel 5. Nilai kinerja masing-masing faktor

\begin{tabular}{|c|c|c|c|c|c|c|c|}
\hline & \multicolumn{5}{|c|}{ NILAI } & \multirow[t]{2}{*}{ TOTAL } & \multirow[t]{2}{*}{ NIKi } \\
\hline \multirow[t]{2}{*}{ VARIABEL } & STP & $\mathrm{TP}$ & $\mathrm{B}$ & $\mathrm{P}$ & SP & & \\
\hline & 1 & 2 & 3 & 4 & 5 & & \\
\hline 1 & 4 & 21 & 30 & 23 & 4 & 82 & 248 \\
\hline 2 & 4 & 17 & 43 & 13 & 5 & 82 & 244 \\
\hline 3 & 1 & 1 & 30 & 42 & 8 & 82 & 301 \\
\hline 4 & 1 & 2 & 25 & 42 & 12 & 82 & 308 \\
\hline 5 & 0 & 6 & 25 & 44 & 7 & 82 & 298 \\
\hline 6 & 1 & 5 & 34 & 34 & 8 & 82 & 289 \\
\hline 7 & 0 & 5 & 46 & 26 & 5 & 82 & 277 \\
\hline 8 & 0 & 5 & 31 & 34 & 12 & 82 & 299 \\
\hline 9 & 1 & 5 & 35 & 31 & 10 & 82 & 290 \\
\hline 10 & 3 & 7 & 17 & 29 & 26 & 82 & 314 \\
\hline 11 & 17 & 25 & 26 & 10 & 4 & 82 & 205 \\
\hline 12 & 1 & 8 & 30 & 31 & 12 & 82 & 291 \\
\hline 13 & 2 & 9 & 41 & 23 & 7 & 82 & 270 \\
\hline 14 & 11 & 18 & 33 & 14 & 6 & 82 & 232 \\
\hline 15 & 16 & 13 & 36 & 10 & 7 & 82 & 225 \\
\hline 16 & 13 & 21 & 28 & 16 & 4 & 82 & 223 \\
\hline 17 & 1 & 7 & 24 & 38 & 12 & 82 & 299 \\
\hline 18 & 1 & 7 & 32 & 36 & 6 & 82 & 285 \\
\hline 19 & 4 & 17 & 40 & 16 & 5 & 82 & 247 \\
\hline 20 & 1 & 11 & 44 & 20 & 6 & 82 & 265 \\
\hline 21 & 9 & 23 & 35 & 9 & 6 & 82 & 226 \\
\hline 22 & 10 & 24 & 32 & 9 & 7 & 82 & 225 \\
\hline 23 & 7 & 10 & 35 & 21 & 9 & 82 & 261 \\
\hline 24 & 6 & 10 & 38 & 18 & 10 & 82 & 262 \\
\hline 25 & 26 & 13 & 23 & 13 & 7 & 82 & 208 \\
\hline & & & GR & ID T & TAL & 2050 & 6592 \\
\hline & & & & & $\mathrm{RA}$ & A-RATA & 3,22 \\
\hline
\end{tabular}

\footnotetext{
Teknosains : Jurnal Sains,Teknologi dan Informatika is licensed under a Creative Commons Attribution-NonCommercial 4.0 International License.
}

Analisis Kepuasan Pelanggan Pada Sekolah Tinggi Teknologi Muhammadiyah Cileungsi-Bogor (Vol.7, No.1) Januari 2020 
Selanjutnya dari penelitian yang telah dilakukan didapatkan tingkat kesesuaian faktor-faktor yang diukur adalah sebagai berikut:

Tabel 6. Nilai tingkat kesesuaian masing-masing faktor

\begin{tabular}{|c|c|c|c|c|}
\hline NO. & VARIABEL & KINERJA & KEPENTINGAN & Tki $\%$ \\
\hline 1 & $\begin{array}{l}\text { Kelengkapan buku-buku referensi di perpustakaan } \\
\text { kampus }\end{array}$ & 3,02 & 4,33 & 69,86 \\
\hline 2 & Kelengkapan laboratorium & 2,98 & 4,46 & 66,67 \\
\hline 3 & $\begin{array}{l}\text { Kualitas dosen (kualifikasi pendidikan dan pengalaman } \\
\text { yang berkaitan dengan mata kuliah yang diampu) }\end{array}$ & 3,67 & 4,59 & 80,05 \\
\hline 4 & Kemampuan dosen mengajar di kelas & 3,76 & 4,55 & 82,57 \\
\hline 5 & Tingkat kehadiran dosen & 3,63 & 4,29 & 84,66 \\
\hline 6 & $\begin{array}{l}\text { Kemudahan prosedur pelayanan administrasi } \\
\text { (pendaftaran, pembayaran dan lain-lain) }\end{array}$ & 3,52 & 4,26 & 82,81 \\
\hline 7 & $\begin{array}{l}\text { Kejelasan dan konsistensi peraturan berkaitan dengan } \\
\text { akademik (perkuliahan, kerja praktek, praktikum, tugas } \\
\text { akhir dan lain-lain) }\end{array}$ & 3,38 & 4,20 & 80,52 \\
\hline 8 & $\begin{array}{l}\text { Pelayanan dan bimbingan dari dosen mata kuliah, dosen } \\
\text { wali dan kaprodi }\end{array}$ & 3,65 & 4,34 & 83,99 \\
\hline 9 & $\begin{array}{l}\text { Keramahan petugas pelayanan di kampus (akademik, } \\
\text { keuangan, perpustakaan dan lain-lain) }\end{array}$ & 3,54 & 4,20 & 84,30 \\
\hline 10 & Kelengkapan sarana ibadah & 3,83 & 4,57 & 83,73 \\
\hline 11 & Kelengkapan sarana olahraga & 2,50 & 3,66 & 68,33 \\
\hline 12 & Letak kampus (strategis, mudah dijangkau dan lain-lain) & 3,55 & 4,05 & 87,65 \\
\hline 13 & Biaya-biaya & 3,29 & 3,89 & 84,64 \\
\hline 14 & Status akreditasi & 2,83 & 4,66 & 60,73 \\
\hline 15 & Status kepemilikan gedung & 2,74 & 4,39 & 62,50 \\
\hline 16 & Kualitas ruang kuliah & 2,72 & 4,51 & 60,27 \\
\hline 17 & Fleksibilitas waktu kuliah & 3,65 & 4,46 & 81,69 \\
\hline 18 & $\begin{array}{l}\text { Keterkaitan mata kuliah dengan perkembangan } \\
\text { perkembangan zaman }\end{array}$ & 3,48 & 4,41 & 78,73 \\
\hline 19 & $\begin{array}{l}\text { Ketersediaan modul/buku untuk masing-masing mata } \\
\text { kuliah }\end{array}$ & 3,01 & 4,28 & 70,37 \\
\hline 20 & $\begin{array}{l}\text { Ketersediaan tempat makan minum (kantin, kafe dan lain } \\
\text { lain) }\end{array}$ & 3,23 & 4,18 & 77,26 \\
\hline 21 & Keaktifan ikatan alumni & 2,76 & 3,65 & 75,59 \\
\hline 22 & Bursa lapangan kerja & 2,74 & 4,33 & 63,38 \\
\hline 23 & Keaktifan lembaga kemahasiswaan & 3,18 & 4,15 & 76,76 \\
\hline 24 & Kualitas tempat parkir kendaraan & 3,20 & 4,16 & 76,83 \\
\hline 25 & Fasilitas internet & 2,54 & 4,55 & 55,76 \\
\hline
\end{tabular}

Dari data-data yang telah diolah di atas maka dapat dibuat Diagram Kartesius dari Tingkat kepentingan dan Tingkat Kinerja sebagai berikut:

Teknosains : Jurnal Sains, Teknologi dan Informatika is licensed under a Creative Commons Attribution-NonCommercial 4.0 International License.

Analisis Kepuasan Pelanggan Pada Sekolah Tinggi Teknologi Muhammadiyah Cileungsi-Bogor (Vol.7, No.1) Januari 2020 


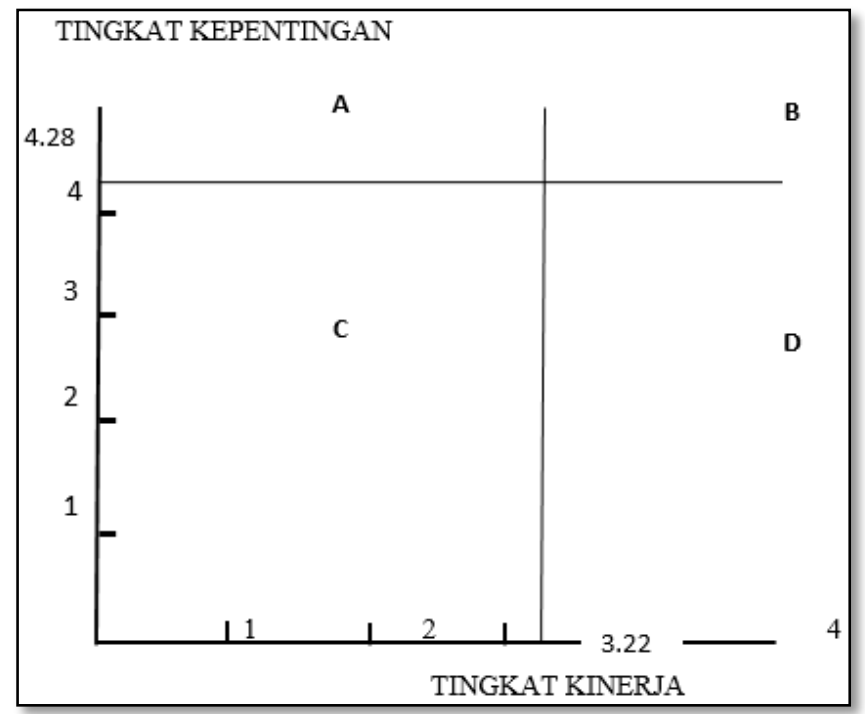

Gamber 2. Diagram Kartesius IPA STTMC Cileungsi

Selanjutnya dari nilai kesesuaian yang didapat (Tabel 5) maka posisi masing-masing atribut atau faktor yang diukur di dalam diagram Kartesius IPA dapat diketahui dengan pasti. Hal itu bisa dilihat di dalam tabel di bawah ini.

Tabel 7. Posisi masing-masing faktor di dalam diagram

\begin{tabular}{|c|l|c|c|c|}
\hline \multicolumn{1}{|c}{ VARIABEL } & X & KINERJA & HARAPAN & POSISI \\
\hline NO. & \multicolumn{1}{|c|}{} & \multicolumn{1}{|c|}{ HA,02 } & 4,33 & A \\
\hline 2 & Kelengkapan buku-buku referensi di perpustakaan kampus & 2,98 & 4,46 & A \\
\hline 3 & $\begin{array}{l}\text { Kelengkapan laboratorium } \\
\text { berkaitan dengan mata kuliah yang diampu) }\end{array}$ & 3,67 & 4,59 & B \\
\hline 4 & Kemampuan dosen mengajar di kelas & 3,76 & 4,55 & B \\
\hline 5 & Tingkat kehadiran dosen & 3,63 & 4,29 & B \\
\hline 6 & $\begin{array}{l}\text { Kemudahan prosedur pelayanan administrasi (pendaftaran, } \\
\text { pembayaran dan lain-lain) }\end{array}$ & 3,52 & 4,26 & D \\
\hline 7 & $\begin{array}{l}\text { Kejelasan dan konsistensi peraturan berkaitan dengan akademik } \\
\text { (perkuliahan, kerja praktek, praktikum, tugas akhir dan lain-lain) }\end{array}$ & 3,38 & 4,20 & D \\
\hline 8 & $\begin{array}{l}\text { Pelayanan dan bimbingan dari dosen mata kuliah, dosen wali } \\
\text { dan kaprodi }\end{array}$ & 3,65 & 4,34 & B \\
\hline 9 & $\begin{array}{l}\text { Keramahan petugas pelayanan di kampus (akademik, keuangan, } \\
\text { perpustakaan dan lain-lain) }\end{array}$ & 3,54 & 4,20 & D \\
\hline 10 & Kelengkapan sarana ibadah & 3,83 & 4,57 & B \\
\hline 11 & Kelengkapan sarana olahraga & 2,50 & 3,66 & C \\
\hline 12 & Letak kampus (strategis, mudah dijangkau dan lain-lain) & 3,55 & 4,05 & D \\
\hline 13 & Biaya-biaya & 3,29 & 3,89 & C \\
\hline
\end{tabular}

Teknosains : Jurnal Sains, Teknologi dan Informatika is licensed under a Creative Commons Attribution-NonCommercial 4.0 International License.

Analisis Kepuasan Pelanggan Pada Sekolah Tinggi Teknologi Muhammadiyah Cileungsi-Bogor (Vol.7, No.1) Januari 2020 
TEKNOSAINS: Jurnal Sains, Teknologi dan Informatika, Vol.7, No. 1, Januari 2020, 43 - 56

http://jurnal.sttmcileungsi.ac.id/index.php/tekno

\begin{tabular}{|c|c|c|c|c|}
\hline 14 & Status akreditasi & 2,83 & 4,66 & A \\
\hline 15 & Status kepemilikan gedung & 2,74 & 4,39 & A \\
\hline 16 & Kualitas ruang kuliah & 2,72 & 4,51 & $\mathrm{~A}$ \\
\hline 17 & Fleksibilitas waktu kuliah & 3,65 & 4,46 & $\mathrm{~B}$ \\
\hline 18 & $\begin{array}{l}\text { Keterkaitan mata kuliah dengan perkembangan perkembangan } \\
\text { zaman }\end{array}$ & 3,48 & 4,41 & B \\
\hline 19 & Ketersediaan modul/buku untuk masing-masing mata kuliah & 3,01 & 4,280 & $\mathrm{C}$ \\
\hline 20 & Ketersediaan tempat makan minum (kantin, kafe dan lain-lain) & 3,23 & 4,18 & $\mathrm{D}$ \\
\hline 21 & Keaktifan ikatan alumni & 2,76 & 3,65 & $\mathrm{C}$ \\
\hline 22 & Bursa lapangan kerja & 2,74 & 4,33 & A \\
\hline 23 & Keaktifan lembaga kemahasiswaan & 3,18 & 4,15 & $\mathrm{D}$ \\
\hline 24 & Kualitas tempat parkir kendaraan & 3,20 & 4,16 & $\mathrm{D}$ \\
\hline \multirow[t]{2}{*}{25} & Fasilitas internet & 2,54 & 4,55 & A \\
\hline & RATA-RATA & 3,22 & 4,284 & \\
\hline
\end{tabular}

Dari hasil yang sudah tergambar pada tabel 6 maka menjadi mudah untuk menentukan tindakan bagi STT Muhammadiyah Cileungsi untuk meningkatkan kepuasan pelanggan yang dalam hal ini adalah para mahasiswa. Secara garis besar tindakan yang perlu dilakukan adalah sebagai berikut:

\section{Kuadran A}

Inilah wilayah kuadran yang harus mendapatkan prioritas untuk pembenahan. Di kuadran ini semua faktor dianggap penting oleh pelanggan tetapi belum bisa dipenuhi dengan baik oleh pihak STT Muhammadiyah Cileungsi. Untuk itu perlu dilakukan tindakan untuk perbaikan. Beberapa faktor itu adalah sebagai berikut:

(1) Kelengkapan buku-buku referensi di perpustakaan kampus

(2) Kelengkapan laboratorium

(14) Status akreditasi

(15) Status kepemilikan gedung

(16) Kualitas ruang kuliah

(22) Bursa lapangan kerja

(25) Fasilitas internet

\section{Kuadran B}

Faktor-faktor yang berada di kuadran ini perlu dipertahankan kinerjanya. Secara umum sudah ada kesesuaian antara harapan pelanggan dan kinerja yang diterima pelanggan yaitu mahasiswa STT Muhammadiyah Cileungsi. Beberapa faktor yang dipertahankan pencapainnya itu adalah sebagai berikut:

(3) Kualitas dosen (kualifikasi pendidikan dan pengalaman yang berkaitan dengan mata kuliah yang diampu)

(4) Kemampuan dosen mengajar di kelas

(5) Tingkat kehadiran dosen

(8) Pelayanan dan bimbingan dari dosen mata kuliah, dosen wali dan kaprodi

(10) Kelengkapan sarana ibadah

(17) Fleksibilitas waktu kuliah

Teknosains : Jurnal Sains, Teknologi dan Informatika is licensed under a Creative Commons Attribution-NonCommercial 4.0 International License.

Analisis Kepuasan Pelanggan Pada Sekolah Tinggi Teknologi Muhammadiyah Cileungsi-Bogor (Vol.7, No.1) Januari 2020 
(18) Keterkaitan mata kuliah dengan perkembangan perkembangan zaman

\section{Kuadran C}

Beberapa faktor yang berada di kuadran $\mathrm{C}$ adalah faktor yang menurut para mahasiswa kurang penting. Tetapi pelaksanaannya oleh STT Muhammadiyah Cileungsi juga biasa-biasa saja. Perbaikan untuk atribut di kuadran ini tidak perlu diberikan prioritas utama. Beberapa faktor itu adalah sebagai berikut:

(11) Kelengkapan sarana olahraga

(13) Biaya-biaya

(19) Ketersediaan modul/buku untuk masing-masing mata kuliah

(21) Keaktifan ikatan alumni

\section{Kuadran D}

Beberapa faktor yang ada di kuadran B adalah faktor yang bagi pelanggan kurang penting, akan tetapi pelaksanaannya berlebihan. Dengan kata lain faktor in dianggap kurang penting oleh para mahasiswa tetapi oleh STT Muhammadiyah Cileungsi dilaksanakan secara baik. Beberapa faktor yang ada di kuadran ini adalah:

(6) Kemudahan prosedur pelayanan administrasi (pendaftaran, pembayaran dan lain-lain)

(7) Kejelasan dan konsistensi peraturan berkaitan dengan akademik (perkuliahan, kerja praktek, praktikum, tugas akhir dan lain-lain)

(9) Keramahan petugas pelayanan di kampus (akademik, keuangan, perpustakaan dan lain-lain)

(12) Letak kampus (strategis, mudah dijangkau dan lain-lain)

(20) Ketersediaan tempat makan minum (kantin, kafe dan lain-lain)

(23) Keaktifan lembaga kemahasiswaan

(24) Kualitas tempat parkir kendaraan

\section{SIMPULAN}

STT Muhammadiyah Cileungsi perlu membuat tindakan untuk meningkatkan kepuasan pelanggan dengan fokus pada faktor-faktor yang penting bagi para mahasiswa sebagai pelanggan dan kinerja faktor-faktor tersebut masih rendah. Beberapa faktor itu adalah sebagai berikut: kelengkapan bukubuku referensi di perpustakaan kampus, kelengkapan laboratorium, status akreditasi, status kepemilikan gedung, kualitas ruang kuliah, bursa lapangan kerja dan fasilitas internet. Dengan memperhatikan tingkat kesesuaian masing-masing faktor tersebut maka urutan prioritas perbaikan adalah sebagai berikut: 1). Fasilitas internet $(55,76 \%), 2)$. Kualitas ruang kuliah $(60,27 \%), 3)$. Status akreditasi $(60,73 \%)$, 4). Status kepemilikan gedung $(62,50 \%)$, 5). Bursa lapangan kerja $(63,38 \%)$, 6). Kelengkapan laboratorium $(66,67 \%), 7)$ Kelengkapan buku-buku referensi di perpustakaan kampus $(69,86 \%)$.

\section{DAFTAR PUSTAKA}

Cox, R. H. (1986). Regulation of contraction in smooth muscle: physiological studies. Progress in Clinical and Biological Research, 219, 187-210.

Durvasula, S., Lysonski, S., \& Mehta, S. C. (1999). Testing the SERVQUAL scale in the business-to-

Teknosains : Jurnal Sains, Teknologi dan Informatika is licensed under a Creative Commons Attribution-NonCommercial 4.0 International License. 
TEKNOSAINS: Jurnal Sains, Teknologi dan Informatika, Vol.7, No. 1, Januari 2020, 43 - 56 http://jurnal.sttmcileungsi.ac.id/index.php/tekno

business sector: The case of ocean freight shipping service. Journal of Services Marketing, 13(2), 132-150. https://doi.org/10.1108/08876049910266040

FAKTOR-FAKTOR KEPUASAN PELANGGAN DAN LOYALITAS PELANGGAN: Studi Kasus Pada CV. Sarana Media Advertising Surabaya. (2004). Jurnal Manajemen Dan Wirausaha. https://doi.org/10.9744/jmk.6.2.pp.123-136

Kotler. (2011). Manajemen Pemasaran di Indonesia: Analisis, Perencanaan, Implementasi dan Pengendalian. Jakarta : Penerbit Salemba Empat. https://doi.org/10.1108/00251749110004961

Lupiyoadi, R. (2014). Pelayanan jasa. Pelayanan Jasa Merupakan Bagian Integral Dengan Penawaran Total, Oleh Karena Itu Perhatian Harus Diberikan Pada Seluruh Aspek Penawaran Untuk Mencapai Keseimbangan Yang Dapat Memuaskan Target Konsumen. https://doi.org/10.1177/0300985809357753

Ong, J. O., \& Pambudi, J. (2014). Analisis Kepuasan Pelanggan Dengan Importance Performance Analysis Di Sbu Laboratory Cibitung Pt Sucofindo (Persero). J@Ti Undip : Jurnal Teknik Industri, 9(1), 1-10. https://doi.org/10.12777/jati.9.1.1-10

Suhendra, A., \& Prasetyanto, D. W. I. (2016). Kajian Tingkat Kepuasan Pengguna Trans Metro Bandung Koridor 2 Menggunakan Pendekatan Importance-Performance Analysis. Jurnal Online Institut Teknologi Nasional.

Supranto. (2001). Pengukuran Tingkat Kepuasan Pelanggan. Untuk Menaikkan Pangsa Pasar. In Edisi Baru.

Teknosains : Jurnal Sains, Teknologi dan Informatika is licensed under a Creative Commons Attribution-NonCommercial 4.0 International License. 